\title{
INTRODUCTION
}

\section{Lorem Ipsum Paris}

\author{
Justin A. Joyce and Dwight A. McBride Northwestern University \\ Douglas Field University of Manchester
}

Keywords: James Baldwin, Paris, terrorism, police shootings, nationalism, transnationalism

We have to say something. Something about the horrific violence of Paris, Orlando, Istanbul, Nice, and Munich. Something as well about the horrific mundanity of the violence also occurring in Fresno, CA, Baton Rouge, LA, Falcon Heights, MN, Dallas, TX, and indeed in countless other cities across the globe. The litany of violent spectacles alluded to above-all these within only a year-seems to demand that we say something in the introduction to our second volume of James Baldwin Review. But what is there to say here about the atrocities we encounter each day? That Baldwin is still relevant? That, prophetically, he saw it all coming?

That would count, in a way, as saying "something." We can point out the ways that James Baldwin's words and legacy were attuned to the intricate emotional and personal turmoil at stake in many of these attacks. Surely, we can join the growing chorus of voices more recently attuned to the continuing relevance of Baldwin's trenchant criticisms: his analyses and critiques of the variety of state-making and community-making forces that still work at dividing our populace along racial, religious, and national lines. These discourses, however, are apt to short-circuit, to dwell and dissolve within their own closed loops. For to speak about Baldwin's continuing relevance and his prophetic voice invites not only endless comparisons between him and more current writers, but also an endless array of disavowals. The conversation quickly becomes a Nostradamus-like search into whether or not Baldwin "saw it coming" or "got it right."

But, again, we have to say something. To introduce this volume's collection of essays without invoking the current geopolitical climate of terror, police violence, astonishingly narcissistic politicians grandstanding on platforms of virulent nationalism winning the hearts and minds of too many people, and a union of Europeans on the cusp of collapsing, seems naïve at best.

Surely, in the face of all these atrocities we have to say something. Like the nowobligatory moment of respectful silence, impassioned denunciations, or bereaved

James Baldwin Review, Volume 2, 2016 ( ) The Authors. Published by Manchester University Press and The University of Manchester Library 
musings that bookend our regularly scheduled programming with alarmingly increased frequency, then, let us say something about Paris. The most recent international conference on James Baldwin - "A Language to Dwell In": James Baldwin, Paris, and International Visions-convened at the American University in Paris, six months after the devastating November 2015 terrorist attacks in the French capital, which left 130 people dead and many others wounded. Remarkably, the conference was well attended. Air-travel warnings, security advisories, and threatlevel indicators seemed to go unheeded as scholars from across the globe gathered in a tensely locked-down Paris to consider the writer's legacy and political relevance-to go about the simple yet transformative task of engaged discussion. The fact that people still came is remarkable. That the lure and power of words overpowered the threat of terrorism is both extraordinary and necessary.

We could go on and on, sentimentalizing the City of Lights, but that would ring false. For surely Baldwin himself was not content simply to romanticize Paris as an image of the Metropole of cosmopolitanism and racial harmony. Instead, Baldwin found it more productive to consider the complexities and conflicts of these intermixtures of clashing affiliations. His early essays on Paris, including "Encounter on the Seine" and "The Discovery of What it Means to Be American," where Baldwin described "the uneasy encounters" among people of African descent in the French capital, are illustrative, as is the complex mixture of race, sex, and nation that underlines David's betrayal of his lover, and himself, in Giovanni's Room (1953). ${ }^{1}$

Baldwin's later work was increasingly attuned to transnational politics, and in particular to the dangers of narrow nationalism. As Baldwin makes explicit in his final novel Just Above My Head (1979), nationalism is a concept upheld by "written history," which is "the vocabulary of power."2 Away from the "vocabulary of power" in the United States, Hall's brother, Arthur, a famous gospel singer, begins to experience life outside of the state's manipulative power. In Paris, he views his lover foremost as French, rather than as white, something he could not have done in New York. In Paris, by contrast, "He [Arthur] has no learned, or willed response to him because Guy never existed for him; neither in his imagination, nor in his life, has he ever been threatened by him - that is, by a Frenchman." Crucially, Baldwin does not romanticize the relative racial harmony of France; rather he draws attention to Guy's experience as a white French soldier during the brutal Algerian War. And in a turn reminiscent of the French writer Jean Genet, Arthur learns that Guy's former lover, Mustapha, is Algerian. As their relationship develops, Baldwin describes how, "without premeditation," both men "are trying to use all that which might divide them to bring them closer together."

Baldwin's work demands an engagement with the complexity of a twentiethcentury geopolitical landscape that continues to be divided by the binaries of black and white, gay and straight, religious or atheist. As the essays in this volume attest, engaging with Baldwin's life, works, and legacies demands nothing less than a thorough and thoughtful commitment to examining the influences and interconnections among a variety of ideological, political, and personal perspectives. For the conflicts between these perspectives-and, it must be said, the conflicts 
among the multiple perspectives each individual wields at any given momentcan and do lead to violence.

McKinley E. Melton's “I've Got a Testimony: James Baldwin and the Broken Silences of Black Queer Men" leads off our volume with high praise for contemporary poet Danez Smith. For Melton, Smith seeks to expose the rigidity of conservative Christian ideologies, while publishing and performing poetry that gives voice to the experiences of black queer communities. Joseph Vogel's article, "'To Crush the Serpent': James Baldwin, the Religious Right, and the Moral Minority," draws on Baldwin's final major essay, “To Crush the Serpent" (1987), to explore Baldwin's evolving conceptions of religion, salvation, and transgression in the context of the Reagan era's religious fervor.

Daniel McClure's essay, "Possessing History and American Innocence: James Baldwin, William F. Buckley, Jr., and the 1965 Cambridge Debate," brings us back to an earlier period, and argues that the event of Baldwin and Buckley's public debate at the Cambridge Union can be read as a signpost in a long historical arc, a moment that anticipated the ways the U.S. would address racial inequality in the aftermath of the civil rights era and the dawn of neoliberalism in the 1970s. David McIvor's essay, “The Struggle of Integration: James Baldwin and Melanie Klein in the Context of Black Lives Matter," brings us back to an earlier thinker, arguing that we cannot fully appreciate the depths of what Baldwin called the "savage paradox" of race without the insights provided by Klein and object relations psychoanalysis.

Mikko Tuhkanen's article, "Watching Time: James Baldwin and Malcolm X," continues along the more cerebral path laid out by McIvor's investigation of psychoanalysis, and moves our exploration into the temporal realm. This volume's featured graduate student essay, Courtney Ferriter's "The Uses of Race and Religion: James Baldwin's Pragmatist Politics in The Fire Next Time," rounds out our opening collection of analytic essays, commenting on the pragmatic strain she sees in Baldwin's work and contrasting this with perhaps the most prominent of Baldwin's literary progeny, Ta-Nehisi Coates.

$J B R$ 's second set of dispatches is a decidedly personal, reflective set, featuring a pair of essays that look at the influence of James Baldwin's works on their authors' own intellectual, and emotional, journeys. Phillip Luke Sinitiere's "James Baldwin: Biographical Dispatches on a Freedom Writer" explores Baldwin's oeuvreand a bit of Baldwin's Paris-en route toward a fuller biography, and Jon-Marc McDonald's essay, "Relatively Conscious: The Enduring Rage of Baldwin and the Education of a White Southern Baptist Queer," grapples with his estrangement from his familial Southern Baptist heritage.

Volume 2's multi-media section features a playlist of songs entitled "Jimmy's Songs: Listening Over James Baldwin's Shoulder." Compiled by Ed Pavlić, this selection of tracks is meant to provide a look into some of the music that helped shape Baldwin's own life and his works. This playlist of songs is available via JBR's YouTube channel, so that beyond merely looking we may have a listen as well to the musicality that was so profoundly important to Baldwin's world and expression.

Finally, our second volume concludes with an overview of current work on 
Baldwin, from both the academic and private sectors. Lynn Orilla Scott's bibliographic essay, "Trends in James Baldwin Criticism 2001-10," surveys the field of Baldwin scholarship during this ground-breaking decade for the renaissance of Baldwin studies. Herb Boyd's piece, "The Public James Baldwin," provides an overview of the New York Humanities Council's numerous public engagements with James Baldwin.

Broadening access and engagement with Baldwin, in casual and complex ways across a variety of publics, is the core mission guiding $J B R$. Pausing here to consider the efficacy of words and writings in the face of real physical violence has been no empty lament. As critics and workers in the world of words, our sacred duty seems as relevant and urgent as it has ever been. For nothing about the events and motivations occurring today so coheres and coalesces with the words, actions, and intentions at work in Baldwin's prose as the simple notion that words matter a great deal in the lives we lead and in the lives we take. To change someone's vocabulary, to invoke new words and new expression is nothing short of changing the world. Reaffirming the power of words may not feel like enough in the struggles at hand today. But prompting ourselves and others to use our words together more carefully, creatively, and collaboratively as we continue to shape our own lives, works, and legacies is, indeed, quite something.

\section{Notes}

1 James Baldwin, "Encounter on the Seine: Black Meets Brown" (1955), in Collected Essays, ed. Toni Morrison (New York, Library of America, 1998), pp. 87-90.

2 James Baldwin, Just Above My Head (New York, Delta Trade Press, 1979), p. 512.

3 Ibid., pp. 482.

4 Ibid., p. 498.

\section{Works Cited}

Baldwin, James, “The Discovery of What it Means to Be American” (1959), in Collected Essays, ed. Toni Morrison (New York, Library of America, 1998), pp. 137-42.

"Encounter on the Seine: Black Meets Brown" (1955), in Collected Essays, ed.

Toni Morrison (New York, Library of America, 1998), pp. 85-90.

_ Just Above My Head (New York, Delta Trade Press, 1979).

\section{Contributors' Biographies}

Justin A. Joyce is a postdoctoral fellow with The Graduate School at Northwestern University. He holds a Ph.D. in English from the University of Illinois at Chicago, where he was thrice an N.C.A.A. Academic All-American as a member of the men's gymnastics team. His work on the American Western genre, gun violence, and self-defense, which has appeared in the journal Western American Literature (2012) and The Last Western: Deadwood and the End of American Empire (Bloomsbury, 2013), is the subject of his first monograph, Gunslinging Justice: The American Culture of Gun Violence in Westerns and 
the Law, currently under review with Manchester University Press. Co-editor of two posthumous publications, The Delectable Negro: Human Consumption and Homoeroticism in U.S. Slave Culture by Vincent Woodard (NYU Press, 2014) and Racial Blackness and the Discontinuity of Western Modernity by Lindon Barrett (University of Illinois Press, 2013), Joyce's work in African American literature and theory has also appeared in The Oxford Handbook of the African American Slave Narrative (Oxford University Press, 2014), and The Historical Guide to James Baldwin (Oxford University Press, 2009). Co-editor of A Melvin Dixon Critical Reader (University Press of Mississippi, 2006), Joyce is currently co-editing two collections of critical essays, Critical Terms for African American Studies (SUNY Press) and Whose Beloved Community: Black Civil and LGBT Rights (University of Illinois Press).

Douglas Field is a senior lecturer in 20th-century American Literature at the University of Manchester. He is the editor of American Cold War Culture (Edinburgh University Press, 2009), A Historical Guide to James Baldwin (Oxford University Press, 2009), and the coeditor of a special issue on James Baldwin for African American Review (2013). He is the author of James Baldwin (Writers and Their Work, 2011) and All Those Strangers: The Art and Lives of James Baldwin (Oxford University Press, 2015). Field's work on American literature and culture has been published in journals including Callaloo, English Literary History, African American Review, and Literature and Theology, as well as the Times Literary Supplement, where he is a frequent contributor. His current projects include curating an exhibition of Jeff Nuttall's work (2016-17).

Dwight A. McBride is the Associate Provost for Graduate Education, Dean of the Graduate School, and Daniel Hale Williams Professor of African American Studies, English, and Performance Studies at Northwestern University. An award-winning author of numerous publications that examine connections between race theory, black studies, and identity politics, McBride is the editor of James Baldwin Now (NYU Press, 1999), and co-editor of a special issue of Callaloo: A Journal of African-American and African Arts and Letters entitled "Plum Nelly: New Essays in Black Queer Studies" (2000). McBride's other works include Impossible Witnesses: Truth, Abolitionism, and Slave Testimony (NYU Press, 2002), Black Like Us: A Century of Lesbian, Gay and Bi-Sexual African American Fiction (Cleis Press, 2011), and Why I Hate Abercrombie and Fitch: Essays on Race and Sexuality (NYU Press, 2005). McBride has co-edited several collections and posthumous volumes, including A Melvin Dixon Critical Reader (Mississippi University Press, 2006), Racial Blackness and the Discontinuity of Western Modernity by Lindon Barrett (University of Illinois Press, 2013), and The Delectable Negro: Human Consumption and Homoeroticism within U.S. Slave Culture by Vincent Woodard (NYU Press, 2014). He is currently at work on two new book manuscripts, tentatively titled "Poetics, Politics, and Phillis Wheatley" and "White Lies in the Republic: Race, Sexuality, and the Law." 